\title{
ジクロフェナックナトリウム製剤の品澌と純度*1
}

宮田一好, 庄野文章, 水口和生, 高杉益充 徳島大学医学部附属病院薬凨部*2

\section{Pharmaceutical Properties and Purities of Diclofenac Sodium Preparations*1}

\author{
KazUYoshi Miyata, Fumiaki Shono, \\ KazUO MinakUChI, and MASUmitsu TAKasugi
}

Department of Pharmacy, Tokushima University Hospital*z

(Received April 4, 1983)

\begin{abstract}
The relationship between in-vitro pharmaceutical properties and bioavailability of commercially available diclofenac sodium was described in the previous paper showing results of our general pharmaceutical tests and determination of the concentration in human plasma. Further studies were conducted this time to detect residual organic solvents in drugs, to measure the quantity of diclofenac by the ultraviolet absorption method, and to make quantitative analysis of diclofenac by atomic absorption spectrophotometry. The quantitative values of the diclofenac preparations tested were in agreement with one exception where the value was very low. On the other hand, the atomic absorption spectrophotometry study showed that some of the products contained approximately $30 \%$ of potassium salt although they were labelled sodium salt. Furthermore, the gas chromatography study showed the presence of $100 \mathrm{ppm}$ or more ethanol and/or isopropanol residuals in several products.
\end{abstract}

Keywords—_iclofenac sodium; pharmaceutical tests; residual organic solvents; ultraviolet absorption method; atomic absorption spectrophotometry; gas chromatography

\section{はじめに}

著者らはすでに市販のジクロフェナックナトリウム (以下 diclofenac・Na と略す) 製昘品質に関して, 一般的な薬剤学的試験およびヒトにおける血中濃度測定 を行い, in vitro における品質試験とバイオフベイラビ リティとの関係について報告した. ${ }^{11}$ その後さらに製剤 学的評価の一環として, 製品中の異物という点について 検討を重ねた結果，主成分である diclofenac・Na 以外 にジクロフェナックカリウム（以下 diclofenac・K と略 す）が約 $30 \%$ 混在している製品が存在することが示唆

*1 日本薬学会中国四国支部年会（昭和 56 年度）で発 表.

*2 徳島市蔵本町 2 丁目 $50 ; 50$, Kuramoto-cho, 2chome, Tokushima-shi, 770 Japan
されたまた，ある錠剤では溶媒臭を発するものがあ り，これは製造工程で使用された溶媒が除去されずに残 留しているすのと考えられる.

そこで今回は製剤中に残留する有機溶媒の検索, 紫外 吸光度法を用いたジクロフェナックの定量試験および原 子吸光分析法によるジクロフェナックの塩の定量分析を 行い，検討を加えたので報告する．

\section{実 験 の 部}

\section{1. 试 料}

実験に供した 9 社の製品は，すべて 1 錠中 diclofenac ・Na を $25 \mathrm{mg}$ 含有すると表示された黄色フィルムこ 一ト錠である． 9 製品のロット番号を Table 1 に示し た。 
Table 1. Diclofenac $\cdot \mathrm{Na}$ Tablets Used for Study

\begin{tabular}{cl}
\hline Sample & Lot No. \\
\hline A & 00391 \\
B & RE01RF10 \\
C & J3 \\
D & RG21G81 \\
E & CD11 \\
F & HH123R \\
G & ECG2578 \\
H & 0023141 \\
I & JD11 \\
\hline
\end{tabular}

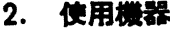

日立 124 型分光光度計，島津 AA610 型原子吸光分光 光度計, 島津 GC-4CM ガスクロマトグラフ, 島津クロ マトパック EIA, 日本電子 JMS-D300 ガスクロマト質 量分析計

\section{3. ジクロフェナックの定}

既報》）之同様に吸光光度法に上り波長 $276 \mathrm{~nm}$ におけ ろジクロフェナックの吸光度を测定し，含量を求めた。

\section{4. ナトリウムムよびカリウムの定}

原子吸光分光光度計を用いて, 検量線法により行っ た2).

1）検量線の作成お.上び検討

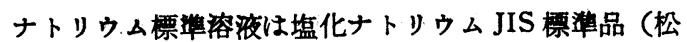
永化学）を用い，脱イオン水で適宜希 积 し，0，0.2, $0.4,0.6,0.8,1.0,1.2,1.5 \mathrm{ppm} の 8$ 点について, また，カリウム標準溶液には塩化カリウム標涿品（メル $\eta$ 社 Suprapur) を用い, 0, 0.5, 1.0, 1.6, 2.0, 2.4，3.0ppm の 7 点について，それぞれの標準溶液を調 製した。ナトリウム標弾溶液には，それぞれカリウムを $1.0 \mathrm{ppm}$ オ゙つ，カリウム標灌溶液には，それぞれナトリ

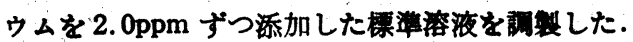

この操作方法化より得たナトリウム用検量線（ $\mathrm{y}=$ 126.08x - 5.70, $\mathrm{r}=0.999$. カリウム $1 \mathrm{ppm}$ 添加 $\mathrm{y}=$ 129.57x-2.8, $\mathrm{r}=0.999)$, カリウム用検共 $(y=$ 42.38x -1.7, $\mathrm{r}=0.998$. ナトリウム $2 \mathrm{ppm}$ 添加 $\mathrm{y}=$ 44. $2 x-5.9, r=0.995)$ は, 吸光度と濃度との関係がす へてて直線性を示した。またナトリウムおよびカリウムの 相互干涉は汪とんど見られなかった。

\section{2)、武料溶液の調製}

粉磁した試料約 $110 \mathrm{mg}$ を精密に量り，脱イオン水 $30 \mathrm{ml}$ を加えて, $70^{\circ} \mathrm{C}, 15$ 分間加熱振とうし正確に $50 \mathrm{ml}$ とす る。これを逞心分崔し，上澄液を試料原液とする。この 試料原液任希硝酸 $1 \mathrm{ml}$ を添加後, 脱イオン水でナトリ
ウム濩度が $1.0 \mathrm{ppm}$ 前後またはカリウム港度 $2.0 \mathrm{ppm}$ 前 後になるよらに適宜希釈する。これらの溶液について検 量線からナトリウム量, カリウム量を求めた。

3）原子吸光分光光度計の条件

\begin{tabular}{lcc}
\hline & $\mathrm{Na}$ & $\mathrm{K}$ \\
\hline Lamp & $\mathrm{L}-233-11 \mathrm{NB}$ & $\mathrm{L}-233-19 \mathrm{NB}$ \\
Wavelength (nm) & 589.0 & 766.5 \\
Lamp current (mA) & 10 & 10 \\
\hline Photoelectron amplifier & $\mathrm{R}-456$ & $\mathrm{R}-456$ \\
Slit width (mm) & 0.1 & 0.1 \\
Band width (A) & 1.9 & 1.9 \\
\hline Burner slot (cm) & 10 & 10 \\
Burner height (mm) & 6 & 6 \\
Acetylene flow rate (1/min) & 2.9 & 2.4 \\
Air flow rate (1/min) & 10 & 10 \\
\hline Expansion & $0-1$ & $0-1$ \\
A A sensitivity & $2.5-2.5$ & $4-6.5$ \\
Response & 2 & 2 \\
\hline
\end{tabular}

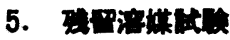

粉碎した試料20錠にnーブタノール10mlを加えて, 油 浴上で共沸蒸留し，その留液にnーブタノールを加えて正 確に $10 \mathrm{ml}$ とし試料溶液とする. ${ }^{3)}$ その試料溶液につい て定性および定量分析をガスクロマトクラフィーにより 行った。）分析には自動面積処理装置を用いて，エタ， ールおよびイソブロパノールの標準溶液をるとに絶対検 量線法により求めた。

さらにガスクロマト質量分析計によって同定を行っ た.

G Cの条件 Column: Chromosorb 102 60-80 mesh, glass $2 \mathrm{~m} \times 3 \mathrm{~mm}$; Injection temp.: $150^{\circ} \mathrm{C}$; Column temp. : $140^{\circ} \mathrm{C}$; Carrier gas $\mathrm{N}_{2}$; Flow rate $40 \mathrm{ml} / \mathrm{min}$.; $\mathrm{H}_{2} 0.8 \mathrm{~kg} / \mathrm{cm}^{2}$; Air $0.9 \mathrm{~kg} / \mathrm{cm}^{2}$.

GC-MS の条件 Column: Chromosorb 102 60-80 mesh, glass $1 \mathrm{~m} \times 3 \mathrm{~mm}$; Injection temp: : $150^{\circ} \mathrm{C}$; Column temp.: $140^{\circ} \mathrm{C}$; Separator temp.: $250^{\circ} \mathrm{C}$; Carrier gas (He): $1.0 \mathrm{~kg} / \mathrm{cm}^{2}$; Ionizing voltage: $20 \mathrm{eV}$; Ionizing current: $300 \mu \mathrm{A}$; Accelerating voltage: 3.0 $\mathrm{kV}$; Ion source temp.: $220^{\circ} \mathrm{C}$.

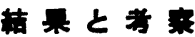

\section{1. ジクロフェナックの主贯值}

Table 2 飞定量試検の結果を示した. 製品 B，C婊 示含量よりかなり低い値を示し，また製品Dは高い値を 示した. 特に製品Cは含量が $89.4 \%$ であり，品筫管理 上では好ましくないと考えられた。 その他の製品は良好 
な値であった。

Table 2. Contents of Diclofenac in Diclofenac • Na Tablets

\begin{tabular}{cc}
\hline Sample & Mean (\%) \\
\hline A & 101.3 \\
B & 93.5 \\
C & 89.4 \\
D & 106.7 \\
E & 99.8 \\
F & 98.3 \\
G & 99.1 \\
H & 100.8 \\
I & 99.9 \\
\hline
\end{tabular}

Values are means for two experiments.

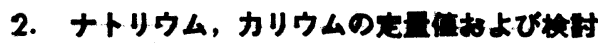

1）製品中にカリウムの混在が示睃された理由

定量試験の結果，製品 Fではジクロフェナックの含量 は98.3\%と良好な値を示した. しかしナトリウムの含有 量は Table 3 に示したよらに他の制品に比べて $5.42 \%$ とかなり低い值を示している，このことはナトリウム塩 以外に他の塩が混在していることを示唆するすのであ る. そこでカリウムについて測定すると Table 3 飞示 したような結果を得た。つまり製品Fではナトリウムを $5.42 \%$ ，カリウムを $3.95 \%$ 含有していることになる. カリウム量 3.95\% をナトリウム量焕算してみると $2.32 \%$ となり，ナトリウムの $5.42 \%$ K加算するとカリ ウムを含有してない他の锤品のナトリウム旦とよく似た 值になる．なお程口用ではカリウム塩が添加都として使 用されることは非常化少ないるのと考えられる.の）以上 のことから，主乘であるジクロフェナックのナトリウム 塩以外飞カリウム塩の混在していることが示唆された。

Table 3. Content of Sodium and Potassium in Diclofenac • $\mathrm{Na}$ Tablets

\begin{tabular}{ccc}
\hline Sample & Na content (\%) & K content (\%) \\
\hline A & 7.73 & - \\
B & 8.19 & - \\
C & 7.54 & - \\
D & 8.02 & - \\
E & 8.32 & - \\
F & 5.42 & 3.95 \\
G & 6.74 & - \\
H & 7.71 & - \\
I & 7.25 & 1.23 \\
\hline
\end{tabular}

Values are means for two experiments.
2）製品 F，I 亿混在する diclofenac・K の含有率 製品 Fは diclofenac・K が $30 \%$, 製品 I は $9 \%$ 混在 している. 計算式は下記のとおりである.

$$
c=b \times \frac{22.99}{39.10} \quad d=\frac{c}{a+c}
$$

diclofenac $\cdot \mathrm{Na}$ 錠中の $\mathrm{a}: \mathrm{Na}$ 含有率 $(\%), \mathrm{b}: \mathrm{K}$ 含 有率 (\%), c : K を $\mathrm{Na}$ 飞換算した含有率 $(\%), \mathrm{d}$ ： diclofenac・K の含有率 $(\%)$.

$22.99: \mathrm{Na}$ 原子量, $39.10: \mathrm{K}$ 原子量

3）定量値におよぼす diclofenac・K の影暗

原末において何パーセントまでの diclofenac・K が 混在しても, diclofenac・Na としての含量規格值 ${ }^{2}$

(98.0 101.0\%) 飞適合するかについて検討した。計 算式は下記のとおりである.

diclofenac・K の含有量を $\mathrm{x} \%$ とすると，

$$
\begin{gathered}
\frac{318.13}{334.42 \times \frac{x}{100}+318.13 \times \frac{100-x}{100}} \times 1.01=0.98 \\
x=59.7
\end{gathered}
$$

diclofenac・Na の分子量 : 318.13

diclofenac $\cdot \mathrm{K}$ の分子量 : 334.42

すなわち diclofenac・K の上限は $59.7 \%$ になる。こ のことから diclofenac・K の混在が $59.7 \%$ 以下である ならば製品FのよらK diclofenac・K が $30 \%$ 混在して いたとしても規格値を満足することになる。

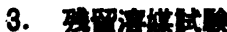

1）製品中に残留するエタノールおよびイソプロパ ール

Fig. 1，2 は製品Hのガスクロマトクララとマススペ クトルを示したすのである. Fig. 1 に沶いて(1)と標示 した $t_{R} 3.11$ と(2)と標示した $t_{R} 5.33$ min とピークが みられるが, (1)のピークはエタノール標準溶液のピー ク，(2)のピークはイソプロパノール標準溶液のピークと 一致した。ささらにマススペクトルによる同定を行った結 果, (1)では $M / Z 31 ， 45 ， 46$ にピークがみられ，また (2)では M/Z 45，59 にピークがみられ，エタノールお よびイソブロパールの標準パターンを示した。

2）エタノールおよびイソプロパノールの定量值

製品中から検出された溶媒量を Table 4 に示した. エタノールは製品 C，D，H認められ，特飞製品 Cは 約 $300 \mathrm{ppm}$ す検出された。また, イソプロパノールは 製品E，H認められ，製品 Hでは約 $500 \mathrm{ppm}$ す検出 された.このことは製造工程において使用されたと思わ れる溶媒が完全に除去されずに残留しているためと考兄 られる。 


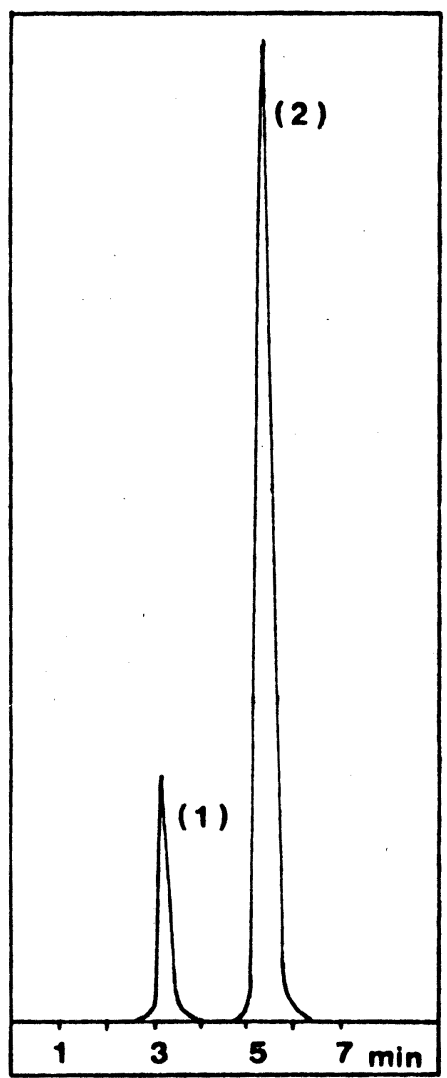

Fig. 1. Gas Chromatogram of Residual Solvent in Diclofenac Sodium Tablet (Sample $\mathrm{H}$ ) peak (1) : ethanol peak (2): isopropanol

Table 4. Content of Residual Solvent in Diclofenac $\bullet \mathrm{Na}$ Tablets

\begin{tabular}{ccc}
\hline \hline Sample & Ethanol & Isopropanol \\
\hline A & - & - \\
B & - & - \\
C & W & - \\
D & H & - \\
E & - & + \\
F & - & - \\
G & - & - \\
H & + & W \\
I & - & - \\
\hline
\end{tabular}

- : 0-30ppm, + : 31-100ppm, H:101200ppm, H: $: 200 \mathrm{ppm}$ over

Each date was determined in triplicate experiments.
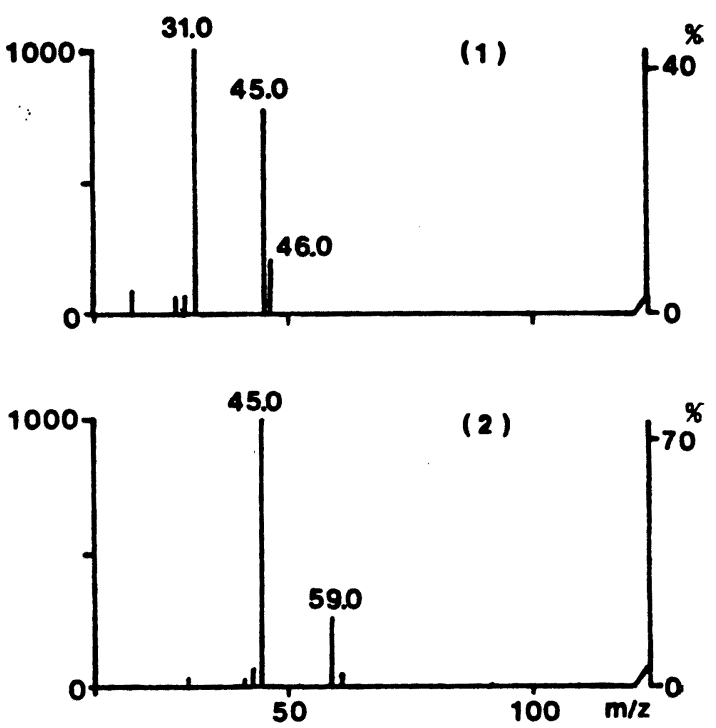

Fig. 2. Mass Spectrum of Residual Solvent in Diclofenac Sodium Tablet (Sample $\mathrm{H}$ )

(1) : ethanol, (2) : isopropanol

䅦

市肘の diclofenac・ $\mathrm{Na}$ 錠 9 製品について製唷学的試 験を行い検討した結果，製品 A， Gがすぐれているよう に思われる.なお，数種類の製品中から溶媒が検出され， 特に一部の製品ではブリスターパック開封時においてす でに明らかな溶媒臭が認められたことに関しては，医薬 品添加物について関心が高まっている現在, 製造工程で の溶媒使用については細心の注意を払い，最終製品完成 前に除去されなければならないものと考える。

また主薬である diclofenac・Na 亿 diclofenac・K が混在していることが示唆された．2製品については医 薬品の表示々いった根本面からも検討する必要があるよ らに思われる. 現在の定量ではジクロフェナックそのむ のを定量することによって diclofenac・Na とみなして いるため, diclofenac・K が混在している場合でむ定量 值が規格を満足してしまうことが判明した。この点につ いては今後定量試験方法に何らかの改善を加える必要が あるのではないかと考光る。

期辞 ガスクロマト質量分析計使用に阥し，で嗳助を 睗わった德島大学薬学部中央機器室, 吉岡泰子先生に深 謝する。

参考交

1）高杉益充, 水口和生, 宮田一好：臨床薬理, 10, 
335 (1979).

2) 後藤秀弘, 池田重良 : “実験化学講座15巻, 分析 化学上, ”日本化学会編, 丸善, 東京, 1957, pp. 199-265; 武者宗一郎, 音在 清輝：“改訂增補機 器分析実験法, ”日本分析化学会近畿支部編, 化学 同人, 東京, 1960, pp. 234-262.

3) 高比良英雄, 寺戸国昭, 佐 藤長 保: 薬誌, 98, 1578 (1978).

4) 高杉益充, 庄野文章, 京谷庄二郎, 水口和生, 宮
田一好：薬物療法, 12, 1433 (1979).

5）荒木峻, 益子洋一郎訳: “有機化合物のスペクト ルによる同定法第 3 版, ”東京化学 同人, 東京, 1976.

6) 井上哲男編：“医薬品添加物,”南山堂, 東京, 1972.

7）日本公定書協会編：“新医薬品の規格・試験法解 説,”薬業時報社, 東京, 1978, pp. 58-60.

\section{舌力哌不间任 血中脂質 $\&$ 動脈壁代謝}
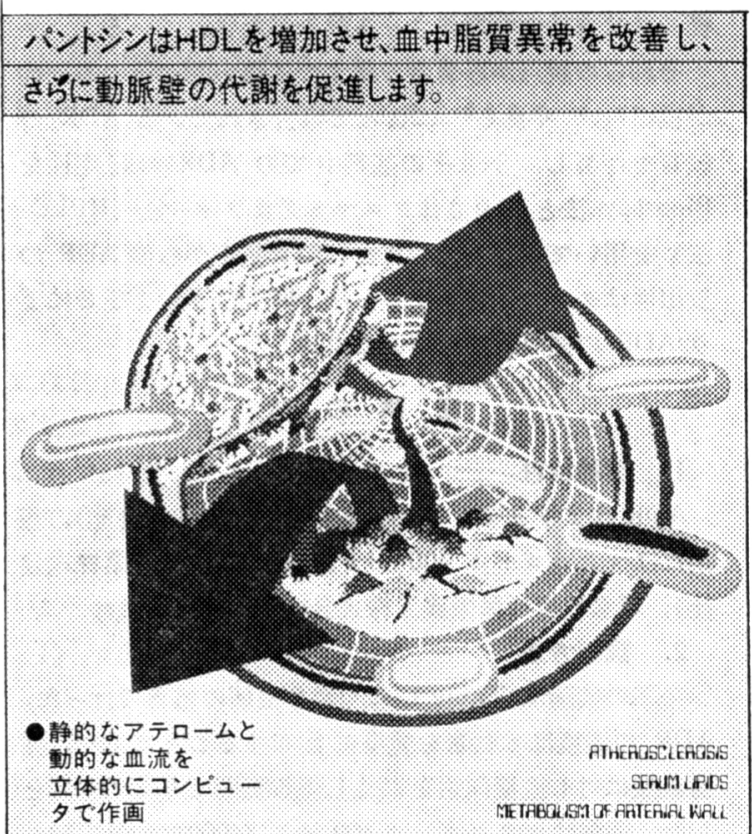

適応症

○下記疾患のうち、パントテン酸の欠乏または代謝障害が関与 すると推定される場合

\section{・脂質代謝障害}

・高コレステロール血症

-弛緩性便秘

・ストレプトマイシンおよびカナマイシンによる副作用の予防および 治療

-急・慢性湿疹

- 血液垁患の血小板数ならびに出血傾向の改善

のパントテン酸の需要が増大し、食事からの掑取が不十分な際の 補給 (消耗性疾患、甲状腺機能元進症、妊産琛、授乳婦など)

○パントテン酸欠そ症の予防および治療

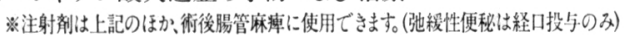

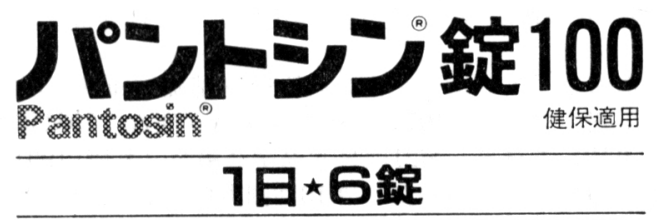

れ用法・用量、使用上の注意は、製品添付交書をご参照〈ださい。

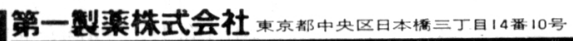

